\title{
Akulturasi Sekolah Bergaya Budaya Bali di Ogan Komering Ulu Timur Sumatra Selatan
}

\author{
Yuyun Nur Astuti ${ }^{1}$, Robby Hidajat ${ }^{2}$ \\ ${ }^{1}$ Mahasiswa S2 Keguruan Seni Rupa, Jurusan Seni dan Desain Fakultas Sastra, Universitas Negeri Malang, \\ Jalan Semarang No. 5 Sumbersari Kecamatan Lowokwaru Kota Malang Jawa Timur 65145 Indonesia \\ ${ }^{2}$ Staf Pengajar Program Studi S2 Keguruan Seni Rupa, Jurusan Seni dan Desain, Fakultas Sastra, Universitas \\ Negeri Malang, Jalan Semarang No. 5 Sumbersari Kecamatan Lowokwaru Kota Malang Jawa Timur 65145 \\ Indonesia \\ 1yuyunastuti.1902518@students.um.ac.id, ${ }^{2}$ robby.hidajat.fs@um.ac.id
}

\begin{abstract}
Artikel ini memaparkan tentang eksistensi budaya Bali yang menjadi suku pendatang di daerah Ogan Komering Ulu (OKU) Timur Sumatera Selatan. Bali merupakan sebuah suku pendatang yang masih menjunjung tinggi adat budayanya dimanapun mereka tinggal. Nilai-nilai luhur yang dipertahankan dan terus dilaksanakan, membuat masyarakat Bali mampu saling bekerja sama dan menjadi sebuah tatanan masyarakat yang sangat solid. Tujuan penelitian ini adalah memahami dan mendeskripsikan bagaimana cara masyarakat Bali sebagai suku pendatang di Kabupaten OKU Timur mempunyai pengaruh terhadap pendidikan. Metode penelitian menggunakan teknik analisis diskriptif kualitatif, sedangkan teknik pengambilan data adalah dengan observasi dan wawancara terhadap SMP Negeri 1 Belitang III di Kabupaten OKU Timur Sumatera Selatan yang arsitektur bangunannya mempunyai corak/gaya arsitektur masyarakat Bali. Hasil penelitian, menunjukkan bahwa budaya Bali membawa pengaruh terhadap lingkungan disekitar. Hal ini dapat dilihat dari suku Bali yang merupakan suku pendatang, mereka tidak hanya membawa budayanya saja namun berpengaruh juga terhadap lingkungan sekitar termasuk lingkungan di SMP Negeri 1 Belitang III.
\end{abstract}

Kata kunci : budaya bali, pendidikan, arsitektur

\section{Acculturation Of Bali Cultural Schools In Ogan Komering Ulu (Oku) East Sumatra South}

This article describes the existence of Balinese culture as an immigrant tribe in the East Ogan Komering Ulu $(\mathrm{OKU})$ area of South Sumatra. Bali is an immigrant tribe who still upholds their cultural customs wherever they live. The noble values that are maintained and continue to be implemented make the Balinese people able to work together and become a very solid community structure. The purpose of this study is to understand and describe how the Balinese as immigrant tribes in East OKU Regency have an influence on education. The research method uses qualitative descriptive analysis techniques, while the data collection technique is by observation and interviews with SMP Negeri 1 Belitang III in East OKU Regency, South Sumatra, whose building architecture has the architectural style of the Balinese people. The results show that Balinese culture has an influence on the surrounding environment. This can be seen from the Balinese who are immigrant tribes, they not only bring their culture but also affect the surrounding environment including the environment in SMP Negeri 1 Belitang III.

Keywords : Balinese culture, education, architecture

Proses Review : 1 - 20 Mei 2021, Dinyatakan Lolos: 31 Mei 2021 


\section{PENDAHULUAN}

Tradisi dan budaya lahir dalam suatu kumpulan masyarakat, setiap kumpulan masyarakat tertentu memiliki cirikhas kebudayaan dan tradisi yang berbeda (Rahmawaty \& Maharani, 2013). Berbagai budaya tersebut merupakan kekayaan yang tak ternilai harganya yang harus selalu dijaga dan dilestarikan. Bahkan pada daerah tertentu menjadi tempat berkumpulnya berbagai etnik karena perpindahan penduduk yang tidak menetap dan berpindah menuju daerah lain (Buchari, 2014). Budaya sendiri merupakan sebuah ide, gagasan dan norma-norma, serta nilai dan peraturan yang bersifat abstrak (Parmadie et al., 2018).

Setiap daerah dapat dijumpai beberapa etnik tertentu yang tinggal dan menetap. Selain hal tersebut, terdepat beberapa etnik yang melakukan perpindahan serta masih tetap mempertahankan budaya yang dibawa dari tanah lahirnya dan tetap melaksanakan kebiasaan sesuai dengan adat istiadat tempat asalnya. Di beberapa daerah, perpindahan penduduk tersebut sudah menjadi sesuatu hal yang lumrah bila mereka membentuk suatu perkumpulan tertentu untuk tetap melaksanakan kebiasaan adat budayanya (Syuhada, 2020). Keadaan tersebut mau tidak mau memaksa untuk hidup berdampingan yang secara tidak langsung menumbuhkan tenggang rasa terhadap masyarakat lain yang juga melaksanakan kebudayaannya.

Sebenarnya masyarakat pendatang yang tetap mempertahankan budaya asalnya, justru kemudian tidak dapat dipungkiri menjadi hal yang unik pada suatu daerah tertentu. Dari keunikan tersebut sebenarnya dapat ditarik kesimpulan bahwa daerah yang multikultural adalah daerah yang kaya akan budaya, daerah yang kaya akan berbagai macam nilai lokal yang perlu terus dijaga dan dilestarikan.

Masyarakat Kabupaten OKU Timur di Sumatera Selatan merupakan masyarakat multikultural (Nurlia et al., 2020). Menjadi salah satu Kabupaten pecahan dari OKU Induk, OKU Timur merupakan sebuah kabupaten multikultural dengan berbagai suku yang tinggal dan menetap disana, meskipun tak dipungkiri suku melayu adalah suku asli masyarakat di Kabupaten OKU Timur. Namun hal tersebut tidak menjadikan masyarakat OKU Timur sendiri menjadi masyarakat yang kemudian mendiskriminasi penduduk dengan etnik tertentu. Justru keberagaman etnik tersebut membuat masyarakat OKU Timur menjadi kian erat dengan berbagai perbedaan serta menjadi salah satu kabupaten yang kaya akan budaya.

OKU Timur merupakan Kabupaten yang mempunyai banyak suku akibat transmigrasi penduduk yang dilakukan dalam beberapa tahap, dengan transmigrasi awal dilaksanakan pada jaman belanda yakni tahun 1937 hingga kemudian diteruskan secara berkala oleh pemerintah.
Suku-suku yang tinggal dan menetap di OKU Timur sendiri adalah suku Komering sebagai suku asli Kabupaten OKU Timur, namun banyak pula suku lain yang menetap disana yang jumlahnya hampir sama dengan suku Komering, diantaranya adalah suku Bali, Suku Komering, suku Jawa, suku Padang, suku Batak, suku Palembang (Mustikasari, 2011).

Masyarakat OKU Timur dikenal sebagai warga yang memiliki toleransi tinggi. Terkadang suatu perhelatan kebudayaan tertentu menjadi acara yang menarik masyarakat untuk dijadikan suatu tontonan yang berfungsi sebagai hiburan. Misalnya saja reog ponorogo, wayang kulit jawa, tari-tarian khas masyarakat melayu yang selalu diadakan dan ditanggap oleh masyarakat OKU Timur untuk memeriahkan acara-acara tertentu seperti khitanan dan penikahan atau acara lainnya.

Sebuah kebiasaan dan kebudayaan yang diwariskan secara turun temurun menjadikannya sebuah tradisi (Wahid et al., 2018). Masyarakat Bali dikenal mempunyai berbagai macam jenis tradisi dan kaya akan nilai budaya yang sangat adiluhung (Renawati, 2019). Tradisi tersebut tidak hanya acara yang dirayakan untuk memeriahkan acara keluarga saja, ada beberapa acara yang digelar untuk kepentingan adat dan agama, salah satunya adalah acara ogoh-ogoh bagi umat hindu. Acara ogoh-ogoh adalah acara umat hindu masyarakat bali yang rutin diadakan setiap tahun di OKU Timur secara meriah. Bahkan perhelatan acara tersebut sering menghadirkan pejabat terkait untuk pembukaan acara. Hal ini membuktikan bahwa sungguhpun masyarakat Bali merupakan masyarakat pendatang di OKU Timur, hal tersebut tak lantas menjadikan masyarakat Bali sendiri terkesampingkan. Justru perhelatan upacara-upacara adat Bali sering disambut antusias oleh masyarakat OKU Timur dan dijadikan sebagai ajang sebuah tontonan untuk hiburan.

Kebiasan-kebiasaan masyarakat Bali di OKU Timur sendiri ternyata juga dilakukan oleh masyarakat Bali di Provinsi Bali. Hal tersebut seperti yang diungkapkan pada penelitian (Karuni \& Suardana, 2018) yang membahas tentang peranan wacana ajeg Bali yang meningkatkan berbagai upacara adat dan agama serta menjadikannya sebagai sebuah rekereasi religius.

Masyarakat Bali merupakan masyarakat yang terbuka dan selektif sehingga mudah beradaptasi dengan berbagai lingkungan (Karuni \& Suardana, 2018). Masyarakat Bali merupakan masyarakat yang tinggal di tempat-tempat tertentu di OKU Timur dengan berciri berkelompok sehingga sering disebut kawasan tempat tinggal dari para masyarakat Bali disebut dengan kampung Bali, selain itu masyarakat Bali adalah masyarakat yang solid dan mempunyai ciri khas menonjol, religius, ramah, terbuka dan berbudaya luhur (Lanang Jelantik, 2017). Oleh karenanya di OKU Timur bangunan-bangunan masyarakat Bali sendiri dapat dicirikan dengan mudah. 
Bangunan masyarakat Bali sendiri sudah terkenal dengan keestetikannya, seperti bangunan pura yang unik dan menawan yang ada didepan setiap rumah masyarakat Bali. Selain hal tersebut hal unik lainnya yang dapat digunakan sebagai penanda adalah persawahan dan perkebunan yang dimiliki masyarakat Bali yang memiliki ciri khusus yakni terdapat tempat untuk meletakkan sesajen di tengahtengah sawah atau kebun yang terbuat dari semen. Bahkan ornamen yang digunakan dapat langsung dikenali ketika melihat bangunan bali adalah jenis ornamen (motif) yang biasa disebut pepatran.

Toleransi yang dilakukan masyarakat OKU Timur membuat masyarakat menomorsatukan kerukunan dan mengesampingkan perbedaan. Hal tersebut terlihat dari antusiasnya masyarakat menyambut perhelatan antarbudaya. Tidak menutup kemungkinan bahwa kebiasaan tersebut dapat berpengaruh kedalam ranah pendidikan. Bukan tidak mungkin suatu institusi pendidikan terpengaruh dengan suatu kebudayaan tertentu baik secara langsung ataupun secara simbolik.

Oleh sebab itu peneliti tertarik untuk memahami dan mendeskripsikan bagaimana cara masyarakat Bali sebagai suku pendatang di Kabupaten OKU Timur mempunyai pengaruh terhadap pendidikan. Sehingga membuat peneliti melakukan penelitian yang berjudul "Potensi Akulturasi masyarakat OKU Timur dalam membentuk lingkungan sekolah bergaya budaya Bali”.

\section{METODE PENELITIAN}

Metode penelitian ini menggunakan diskriptif secara kualitatif. Peneliti menelaah dokumen dan mewawancarai parapartisipanyang berperan sebagai intrumen kunci. Selain itu peneliti juga mengamati hal-hal yang terjadi disekitar tempat penelitian (Rusdiana. A, 2019). Sedangkan teknik analisis deskriptif kualitatif adalah bagaimana seorang peneliti dapat mengolah data dengan cara menggolongkan data, mengklasifikasikan dan menguraikan data sesuai teori yang sudah ada dan digunakan (Alif, 2020).

Hal tersebut senada dengan pendapat Suardi (2018) bahwa deskriptif kualitatif penelitian yang dilaksanakan dengan menggambarkan fenomena terkait sosial secara deskriptif (Suardi, 2018). Dalam penelitian ini pengambilan data menggunakan teknik observasi dan wawancara terhadap SMP Negeri di Kabupaten OKU Timur yang arsitektur bangunannya mempunyai corak/gaya arsitektur masyarakat bali yakni SMPN 1 Belitang III. Dan teknik keabsahan data menggunakan teknik triangulasi sumber. Sumber tersebut didapat dari wawancara kepada kepala sekolah dan guru. Wawancara diperkuat kembali dengan pengamatan secara langsung ke lokasi.

\section{PAPARAN DATA}

Budaya tidak lepas dari adanya kelompok masyarakat tertentu (Hasugian, 2020). Dalam masyarakat tertentu yang kemudian membentuk kebudayaan terntu. Sehingga budaya dan masyarakat merupakan dua hal yang saling keterkaitan.

OKU Timur merupakan sebuah kabupaten multikultural yang terdapat berbagai macam suku didalamnya, salah satunya adalah Bali (Widianti, 2020). Suku Bali di OKU Timur sendiri tinggal menyebar dalam berbagai lokasi. Sehingga tidak dapat dipungkiri bahwa pada saat melewati perkampungan Bali di OKU Timur akan dapat terlihat jelas keunikannya dari segi bangunannya, salah satunya yaitu berbagai pura yang dibangun didepan atau samping rumah masyarakat Bali.

SMP Negeri 1 Belitang III merupakan sebuah sekolah yang terletak di desa Nusa Bakti. Desa Nusa Bakti sendiri merupakan sebuah desa yang letaknya berdampingan dengan desa Nusa Bali. Sehingga bisa dibilang SMP Negeri 1 Belitang III merupakan sekolah yang beridiri berdampingan dengan masyarakat Bali.

Untuk memperkuat temuan data observasi peneliti mewawancarai bapak Muslim (55tahun) selaku kepala sekolah SMPN 1 Belitang III dan Irawanti (24tahun) yang merupakan guru di SMP Negeri 1 Belitang III.

Letak sekolah yang berdampingan dengan kampung Bali menjadi bahan pertimbangan sendiri untuk memutuskan sekolah tersebut dengan beberapa bangunan yang kemudian dibuat bernuansa budaya Bali. Menurut bapak Muslim ( 55 tahun ), SMP Negeri 1 belitang III mencoba tampil berbeda dari sekolah lain, sehingga plang nama sekolah tersebut didesain menggunakan nuansa budaya Bali.

Pembangunan plang nama sekolah sendiri dilakukan oleh swadaya masyarakat setempat dengan diketuai oleh ketua komite sekolah yakni Ketut Sumindre (alm) dengan mendatangkan ahli ukir dari masyarakat Bali di Desa Nusa Bali.

Begitu pula dengan tempat peribadatan agama Hindu, yakni Pura padmasana yang dibangun pada tahun 2019 dengan bahan pertimbangan bahwa sekolah tersebut telah mencapai batas minimal pembangunan tempat peribadatan yang telah ditetapkan oleh kurikulum sekolah.

Pembangunan pura padmasana sendiri merupakan hasil swadaya masyarakat yang merupakan orang tua wali dari para murid yang beragama hindu dan tokoh masyarakat 


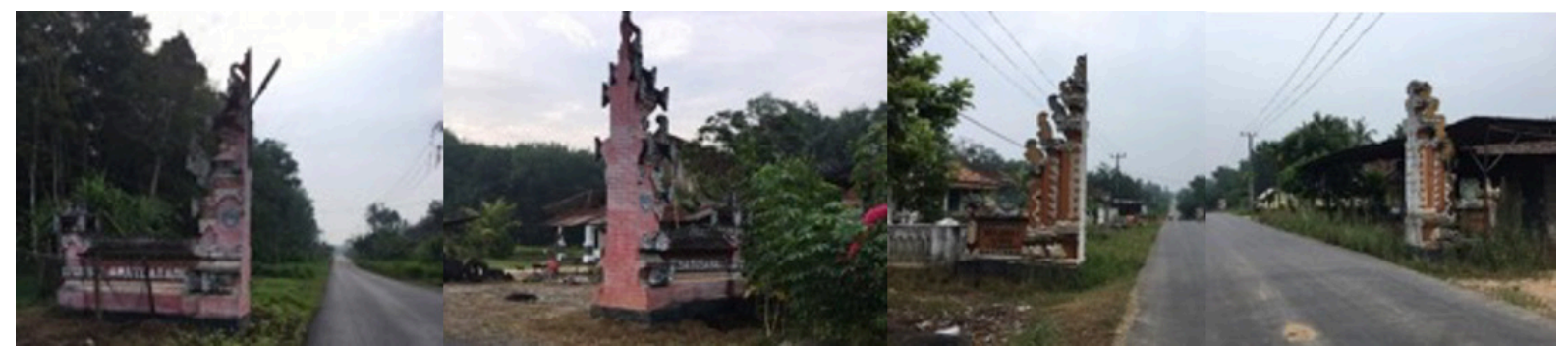

Gambar 1, 2, 3 dan 4. Tugu selamat datang desa Nusa Bali dan Nusa Agung (Sumber: Dok. Pribadi, 2020)

setempat di SMP Negeri 1 Belitang III. Dengan bahan bangunan dibeli langsung dari toko bangunan yang menyediakan perlengkapan bangunan bernuansa Bali. Sebagai bahan pertimbangan dari efisiensi waktu dan biaya sehingga diputuskan untuk membeli desain ornamen dengan motif Bali yang langsung pasang sehingga dapat mempercepat pembangunan dan ditinjau dari segi biaya juga relatif murah. Bahan bangunan sendiri didatangkan dari desa Pemetung Basuki kecamatan Buay Pemuka Peliung Kabupaten OKU Timur Sumatera Selatan. Desa Pemetung Basuki merupakan desa Bali yang jaraknya 49 KM dari SMP Negeri 1 Belitang III.

Hal unik lain adalah di jalan masuk desa Nusa Bali dan desa Nusa Agung terpasang tugu selamat datang dimana desa tersebut mengapit desa Nusa Bakti. Bangunan tugu selamat datang tersebut bernuansa Bali. hal ini terbukti dari senada nya bangunan tersebut dan perbedaan hanya terletak dari segi pewarnaanya saja.

Gambar 1,2,3 dan 4 merupakan bangunan yang mirip dengan gapura bentar pada masyarakat Bali. Meskipun berbeda bentuk dan warna namun tugu selamat datang tersebut arsitekturnya bernuansa Bali. dilihat dari bentuk bangunan yang klasik dengan kesan alami dan pahatan yang begitu indah. Selain hal tersebut bangunan tersebut sama dengan bangunan-bangunan tugu selamat datang di Bali. hal lainnya peneliti juga melihat dari berbagai situs mencoba membandingkan bangunan tugu selamat datang dikampunng Bali lainnya, didapatkan hasil bahwa bangunan tugu di desa Bali di seluruh Indonesia hampir sebagian besar memiliki arsitektur klasik yang kental bernuansa Bali.

\section{ANALISIS DAN INTEPRETASI DATA}

OKU Timur menjadi sebuah kabupaten dengan keberagaman budaya (Widianti, 2020). Beragamnya kebudayaan di OKU Timur sendiri menjadi sebuah kebanggaan pada kabupaten OKU Timur. Beragamnya etnik yang tinggal di kabupaten OKU Timur membuat berbagai macam kegiatan yang dilaksanakan untuk kepentingan adat dan budaya sering kali mudah untuk dijumpai. Mulai dari kebudayaan adat Jawa, Batak, Sunda, Komering dan Bali. Selain hal tersebut, bahkan suatu kebudayaan tertentu bisa dicirikan hanya dari arsitektur bangunanya.
Setiap daerah biasanya memiliki ciri dan corak tersendiri dalam hal apapun termasuk salah satunya dapat dilihat dari sisi gaya bangunannya (Bahar \& Syoufa, n.d.). Dalam setiap daerah, biasanya memiliki arsitektur atau gaya bangunan yang memiliki ciri khas tertentu dan dapat digunakan sebagai penanda suatu masyarakat tertentu. Arsitektur sendiri merupakan ilmu dalam hal merancang atau mendesain suatu bangunan yang dilakukan oleh individu ataupun kelompok tertentu (Widyaevan, 2019).

Rancangan sebuah bangunan sendiri biasanya dibuat untuk memenuhi tujuan atau maksud tertentu dan memiliki nilai tersendiri. Bangunan sendiri setiap pergantian waktu dan musim tertentu selalu mengalami perubahan bentuk dan gayanya. Hal ini dilakukan seiring dengan perkembangan jaman.

Tak terkecuali bangunan sekolah di OKU Timur. Bagaimana memadukan arsitektur sekolah dengan kearifan masyarakat sekitar yang ada sehingga mempunyai nilai estetis dengan makna simbolik tertentu. Bagaimana membuat bangunan sekolah tersebut secara simbolik menjadi sebuah bangunan yang mempunyai nilai kearifan kebudayaan sekitar yang hanya dengan melihatnya secara sekilas pesan yang ada didalamnya dapat tersampaikan dengan baik.

Beberapa bangunan sekolah memilih gaya arsitekturnya berdasarkan kearifan masyarakat yang ada di sekitar sekolah tersebut. Banyak sekolah yang bangunannya berbau kearifan masyarakat sekitar meskipun hanya sebatas gapura gerbang masuk sekolah atau plang nama sekolah saja. Setidaknya hal tersebut menunjukkan bahwa sekolah tersebut berusaha untuk membangun image bahwa sekolah tersebut berdiri ditengah-tengah kebudayaan lokal yang ada disekitar sekolah tersebut.

Berdasarkan sumber data yang telah dikumpulkan melalui observasi dan wawancara, kemudian peneliti menganalisis temuan bahwa dari beberapa SMP Negeri di OKU Timur ditemukan sekolah yang gaya bangunan atau arsitekturnya bergaya Bali. Sekolah tersebut yakni SMP Negeri 1 Belitang III. Ketika berada digerbang sekolah, penyuguhan pemandangan yang tak biasa dengan gaya bangunan bagian depan sekolah menjadi hal utama. Hal yang membuat tak biasa tersebut adalah berdirinya sebuah pura dengan gagah setelah pintu masuk sekolah. Hal tersebut memberi kesan dan gambaran bahwa sekolah tersebut merupakan sekolah 


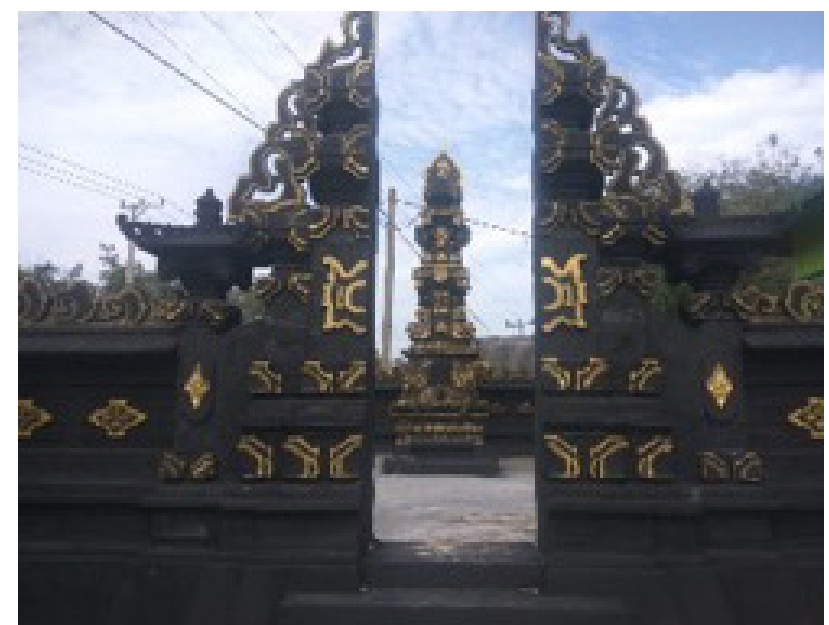

Gambar 5. Pura Padmasana SMPN 1 Belitang III (Sumber: Dok. Pribadi, 2020)

dengan murid-murid sebagian besar adalah orang Bali.

Gambar 5 merupakan pura padmasana di SMPN 1 Belitang III yang digunakan sebagai tempat beribadah umat hindu untuk mendukung kegiatan mata pelajaran agama Hindu di SMPN 1 Belitang III hal ini berdasarkan penuturan Irawanti,S.Pd (24 tahun). Bangunan pura tersebut memiliki dasar cat berwarna hitam dengan hiasan motif berwarna gold. Namun motif yang terdapat pada bangunan pura padmasana di SMP Negeri 1 Belitang III nampak berbeda, motifnya terlihat sederhana dan tidak meninggalkan kesan yang elegan. Kesan sederhana disini dapat dilihat karena bangunan pura padmasana disini menggunakan tehnik cetakan dan tidak diukir secara langsung. Sedangkan motif ornamen pada pura padmasana adalah perpaduan motif flora dan garis. Selain bangunan pura yang berfungsi sebagai tempat menjalankan kegiatan beribadah, bangunan lain dari SMP Negeri 1 Belitang III yang arsitekturnya mengambil dari arsitektur Bali adalah pada plang nama sekolah.

Melihat plang SMP Negeri 1 Belitang III sudah dapat dipastikan bahwa ornamen pada plang tersebut bergaya adat Bali. Ornamanen adat Bali sendiri mempunyai keunikan tersendiri dengan bentuk yang mengedepankan unsur-unsur tradisional didalamnya. Setiap ornamen adat Bali tentunya memiliki filosofis tersendiri.

Gambar 8 merupakan ornamen pondasi dari plang nama sekolah SMPN 1 Belitang III. Ornamen tersebut ada pada sisi kanan dan kiri bagian bawah Plang nama sekolah sehingga terkesan berfungsi sebagai penyangga.

Menurut Suryada (2014) dalam artikelnya menyebutkan bahwa ragam hias yang berbentuk kepala gajah dengan belalai yang melengkung kebawah disebut juga dengan karang gajah. Filosofi dari hewan gajah adalah besar, tinggi dan kuat (Suryada, 2014).
Penempatan karang gajah pada pondasi dasar bangunan plang nama sekolah tersebut memiliki filosofi bahwa bangunan tersebut kokoh dan kuat. Hal ini karena gajah merupakan hewan yang kuat, gajah sendiri dilambangkan sebagai dewa yang bijaksana, arif dan pandai yang dalam pewayangan dalam dilihat sebagai ganesha (Rai Remawa, 2016).

Dewa ganesha sendiri dipercaya sebagai dewa lambang pendidikan, sastra dan penyebar ilmu pengetahuan. Sehingga mempunyai filosofi yang tepat apabila disandingkan dengan sekolah yakni SMPN 1 Belitang III yang merupakan tempat menuntut ilmu para siswa.

Kemudian dapat disimpulkan bahwa penggunaan pondasi berbentuk karang gajah pada penyangga dari plang nama sekolah adalah SMPN 1 Belitang III yang merupakan institusi pendidikan yang menyebarkan ilmu pengetahuan secara arif dan bijaksana.

Dalam gambar 9 merupakan ornamen floralistik. Ornamen floralistik juga familiar disebut dengan pepatran, yang merupakan ornamen pada adat Bali yang memiliki pola garis lengkung berulang dan dipadukan dengan unsur daun (Wijaya, 2018). Ornamen tersebut diambil dari bentuk tumbuhan yang merambat yang dikombinasikan dengan motif lain.

Ide dasar pepatran banyak diambil dari bentuk-bentuk tumbuhan flora dengan bentuk daun, putik, bunga, dan ranting yang berulang-ulang. Filosofi dari pepatran sendiri merupakan tumbuhan yang diambil dari alam yang bermakna dapat memberi perlindungan pada manusia dari rasa takut, panas dan haus yang dapat memberikan rasa nyaman pada manusia yang tinggal dilingkungan bangunan yang dihiasi peptaran (Hartanti \& Nediari, 2014).

Jika ditarik kesimpulan dari fungsi dan makna pepatran yang terdapat pada plang nama SMPN 1 Belitang III memiliki filosofis bahwa sekolah ini diharapkan menjadi tempat menuntut ilmu yang nyaman bagi para siswa, yang dapat menghilangkan dahaga akan ilmu pengetahuan. Dalam hal ini dapat disimpulkan bahwa sekolah ini berdiri dengan bangunan yang bernuansa adat Bali yang dapat dilihat dari arsitektur dan ornamennya. Banyak kemungkinan yang terjadi dalam pemutusan pembangunan nuansa adat Bali. Jika dilihat dari letak geografisnya SMP Negeri 1 Belitang III merupakan SMP yang letak desanya bersebelahan dengan desa Nusa Bali.

Nusa Bali sendiri merupakan sebuah desa yang sebagian besar didiami oleh masyarakat Bali. Hal ini terbukti dari banyaknya pura keluarga yang berjejer indah disepanjang jalan saat melalui desa Nusa Bali.

Desa Nusa Bali merupakan salah satu dari desa Bali yang ada. OKU Timur sendiri sudah terkenal menjadi litle Balinya Sumatera Selatan. Hal ini dikarenakan beberapa 


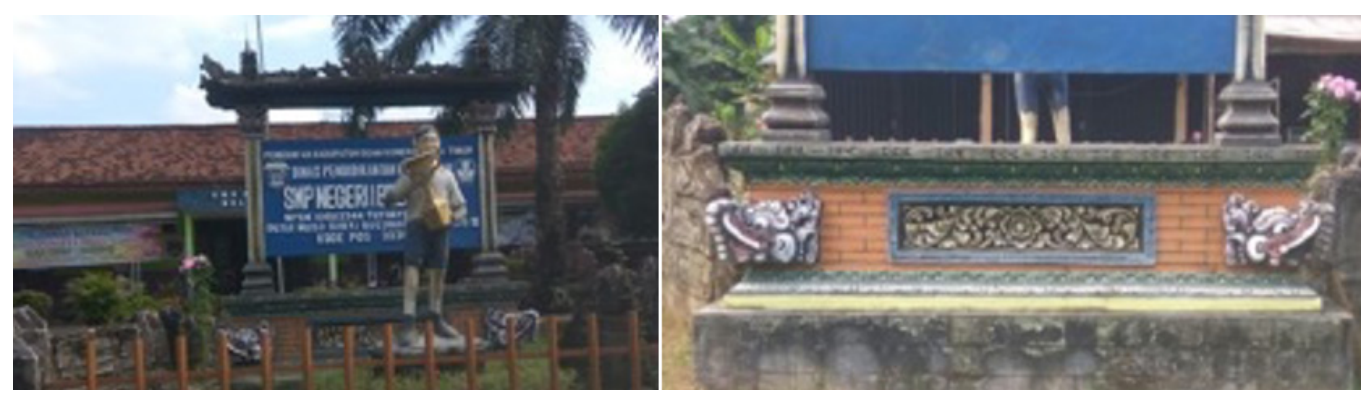

Gambar 6 dan 7. Plang Sekolah SMPN 1 Belitang III (Sumber: Dok. Pribadi, 2020)

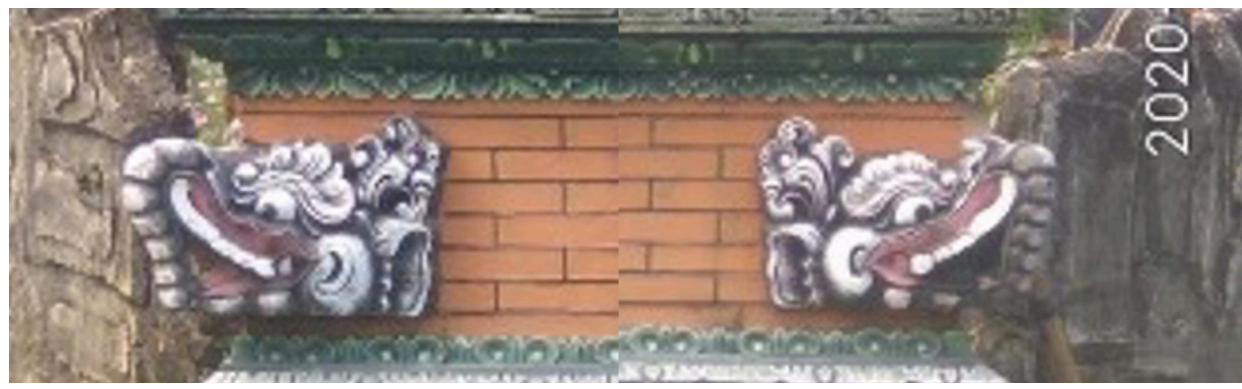

Gambar 8. Ornamen karang gajah (Sumber: Dok. Pribadi, 2020)

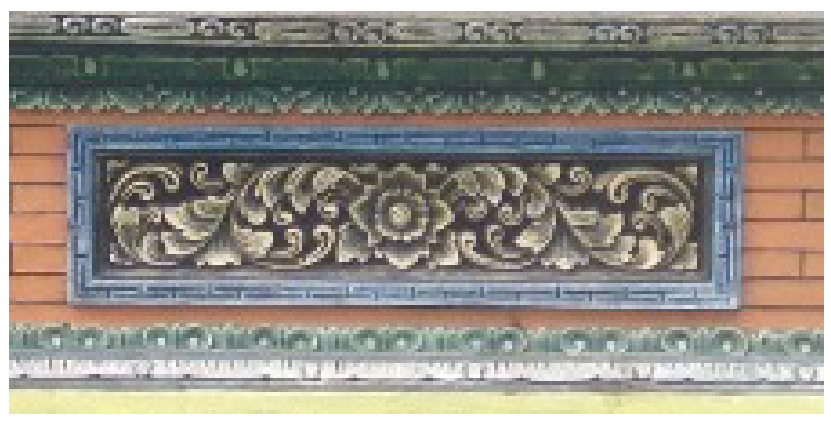

Gambar 9. Ornamen flora pada plang nama SMPN 1 Belitang III

(Sumber: Dok. Pribadi, 2020)

desa di OKU Timur didiami oleh masyarakat Bali yang masih menjaga dengan sangat baik adat budaya asli mereka. Jarak desa Nusa Bali dengan desa Nusa Bakti lebih tepatnya ke SMP Negeri 1 Belitang III sendiri hanya berjarak $2.1 \mathrm{KM}$. dengan jarak tempuh menggunakan roda empat hanya 6 menit saja. Merupakan jarak yang begitu dekat.

Selain itu peneliti mengadakan wawancara dengan Kepala Sekolah SMPN 1 Belitang III bapak Muslim ( 55 tahun ) guna memperkuat temuan data dilapangan. Bapak Muslim (55tahun) adalah kepala sekolah yang dahulunya merupakan guru SMP Negeri 1 Belitang III sejak dari CPNS, sehingga beliau mengetahui seluk beluk dari sekolah ini.

Menurut Bapak Muslim Muslim (55 tahun) bahwa dalam kurikulum sekolah terdapat batas minimal dalam menyiapkan sarana peribadatan didalam sekolah, apabila sudah cukup syarat menjadi kewajiban kepada pihak sekolah untuk menyiapkan sarana peribadatan agar siswa memiliki tanggung jawab keimanan dari masing-masing agama. Selain hal tersebut faktor pendukung lainnya adalah siswa dari masyarakat suku Bali yang bersekolah di SMP Negeri 1 Belitang III sendiri sekitar 158 dari 749 siswa. Bapak muslim (55tahun) juga menjelaskan apabila terdapat kegiatan sekolah, pihak sekolah sendiri selalu berusaha untuk menampilkan seni tari Bali pada berbagai acara kegiatan sekolah baik diluar maupun didalam sekolah.

Penjelasan lain juga disampaikan bapak muslim (55tahun) bahwa sekolah mencoba melakukan pendekatan dengan orang tua siswa, karena kebetulan pada saat itu tidak adanya bantuan dari pemerintah terkait. Ternyata hal positif tersebut direspon secara baik oleh para wali murid yang beragama hindu dan tokoh masyarakat terkait sehingga apa yang menjadi keinginan tersebut dapat terwujud melalui swadaya masyarakat.

Pura yang dibangun pada sekolah SMP Negeri 1 Belitang III ini berdiri pada tahun 2019. Bahan bangunan pura tersebut berupa cetakan ornamen bergaya Bali. Untuk pembangunan pura dilingkungan sekolah SMP Negeri 1 


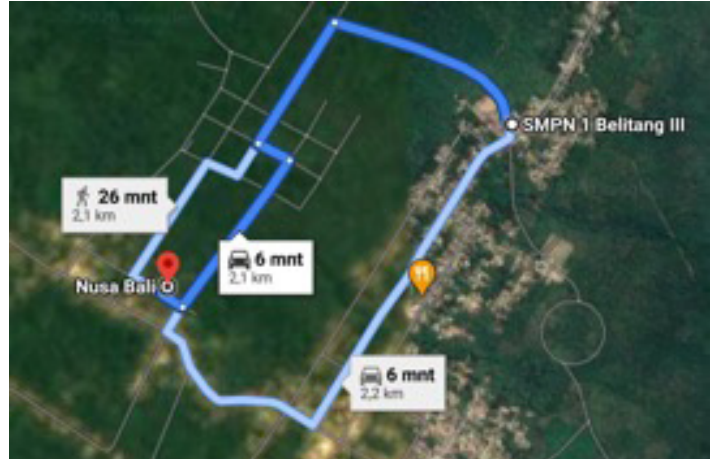

Gambar 10. Peta jarak lokasi desa Nusa Bali dengan SMPN 1 Belitang III yang berada di desa Nusa Bakti (Sumber: Dok. Pribadi, 2020)

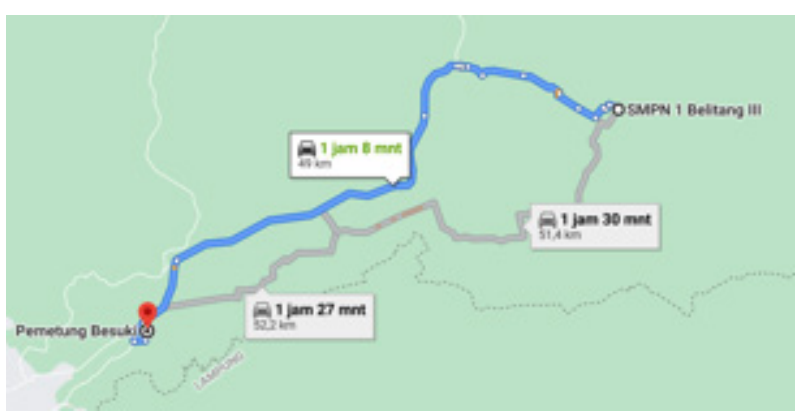

Gambar 11. Peta jarak sekolah dengan toko bangunan di desa Pemetung Basuki (Sumber: Dok. Pribadi, 2020)

Belitang III dilakukan dengan membeli langsung bahanbahannya dari toko bangunan di Desa Pemetung Basuki Kecamatan Buay Pemuka Peliung. Desa Pemetung Basuki merupakan desa bali yang jaraknya dari SMP Negeri 1 Belitang III dikecamatan Belitang III berjarak $49 \mathrm{KM}$. yang berjarak tempuh 1 jam 27 menit menggunakan kendaraan roda 4.

Pembelian bahan ke desa Pemetung Basuki sendiri menjadi alasan utamanya adalah faktor biaya yang lebih murah dan waktu yang cepat karena tinggal pasang saja. Apabila membuat ukiran sendiri dengan mendatangkan ahli ukir, biayanya terlalu mahal dan dibutuhkan waktu yang relatif lama.

Sedangkan plang nama sekolah sendiri pembuatannya dilakukan oleh masyarakat Bali dari Nusa Bali dengan mendatangkan ahli ukir dari Nusa Bali. Pembuatan Plang nama sekolah di SMPN 1 Belitang III diketuai oleh ketua komitenya bernama bapak Ketut Sumindre yang beralamat di Nusa Bali yang kebetulan sekarang sudah meninggal dunia.

Berdasarkan keterangan dari Bapak Muslim (55tahun) pengukiran pada plang nama sekolah tersebut dilakukan dengan pengukiran langsung secara manual. Plang nama sendiri sengaja dibuat dengan gaya Bali dikarenakan dua faktor. Yang pertama karena ingin memiliki hal unik yang berbeda dari sekolah lain di OKU Timur, yang kedua sekolah SMP Negeri 1 Belitang III sendiri merupakan SMP
Negeri yang dibangun dekat dan berdampingan dengan masyarakat Bali, sehingga faktor-faktor tersebut menjadi penguat untuk menambah gaya Bali pada bangunan sekolah tersebut. mengambil gaya bangunan dari budaya masyarakat setempat yaitu bergaya Bali yang bertujuan sebagai identitas sekolah.

Lingkungan masyarakat dengan kebiasaan adat budaya yang kental berdampak dalam berbagai bidang. Masyarakat Bali yang merupakan sebuah suku pendatang tidak hanya sekedar membawa dirinya dan budayanya saja akan tetapi suku Bali juga membawa adat budayanya. Yang budaya tersebut ditanamkan pada setiap anak. Selain itu masyarakat Bali mempunyai seni yang begitu menakjubkan dan diimbangi dengan kebudayaannya yang dinamis dan unik (Pratiwi, 2017). Hal ini diperkuat dengan mengamati video pada youtube dalam acara festival seni dan bazar yang diadakan di kecamatan belitang III. Video tersebut merupakan dokumen milik Deni Saputra yang menunjukan berbagai pertunjukan mulai dari tarian tradisional Bali yang dibawakan oleh siswa siswi Bali.

\section{SIMPULAN}

Kebudayaan dalam suatu masyarakat sebenarnya dipengaruhi oleh lingkungan di sekitar. Suku Bali merupakan suku pendatang yang tinggal dan menetap di lingkungan Kabupaten OKU Timur. Masyarakat Bali di OKU Timur selalu aktif dalam kegiatan berbudaya, selain itu masyarakat Bali yang tinggal di OKU Timur juga memiliki cirikhas dari segi arsitektur bangunan pura dan tempat pertemuan lainnya yang masih kental dengan nuansa Bali. Hal tersebut berpengaruh terhadap lingkungan disekitar masyarakat Bali di OKU Timur terutama di lingkungan sekolah. Kearifan lokal antarbudaya ini memiliki pengaruh kuat dan berkesinambungan yang kemudian dapat diterima dan dipahami oleh masyarakat setempat.

Menilik dari segi arsitektur bangunannya, SMPN 1 Belitang III adalah sekolah yang mengadaptasi lingkungan sekitar sebagai identitas sekolah, sehingga tema arsitektur bangunannya bergaya Bali. SMP Negeri 1 Belitang III membuat pengakuan identitas lokal desa Bali yang ada di OKU Timur, padahal notabennya OKU Timur sendiri adalah daerah suku Komering (Melayu). Hal tersebut membuat SMP Negeri 1 Belitang III menjadi sekolah berciri khas Bali.

Sehingga dapat disimpulkan bahwa masyarakat Bali sebagai suku pedatang memiliki pengaruh besar untuk lingkungan sekitar salah satunya adalah arsitektur bangunan sekolah. Dalam hal ini masyarakat Bali sebagai masyarakat pendatang tidak hanya membawa budayanya saja namun juga memiliki peran besar membentuk lingkungan sekitar termasuk salah satunya lingkungan sekolah dengan nuansa budaya Bali. 


\section{DAFTAR RUJUKAN}

Alif, M. (2020). Analisis penyajian laporan keuangan pada koperasi unit desa makmur di desa benawa kabupaten oki. Universitas Tridinanti.

Bahar, Y. N., \& Syoufa, A. D. E. (n.d.). Teori dan Filosofi. Buchari, S. A. (2014). Kebangkitan etnis menuju politik identitas. Yayasan Pustaka Obor Indonesia.

Hartanti, G., \& Nediari, A. (2014). Sebagai Upaya Konservasi Budaya Bangsa Khususnya pada Perancangan Interior. Humaniora, 5(1), 521-540.

Hasugian, N. (2020). Struktur Tor-tor Sorangan Na Hinamiahan Dalam Ritual Penabalan Sisingamangaraja di Sanggar Budaya Sion Nauli Kecamatan Parlilitan Kabupaten Humbang Hasunduta. Universitas Negeri Medan.

Karuni, N. K., \& Suardana, I. W. (2018). Wacana “Ajeg Bali” Pada Seni Kerajinan Sarana Upacara Di Gianyar Bali. Mudra Jurnal Seni Budaya, 33(1), 26. https://doi. org/10.31091/mudra.v33i1.321

Lanang Jelantik, I. G. (2017). Membangun Karakter Berbasis Pendidikan Seni Budaya di Sekolah. In Membangun Karakter Berbasis Pendidikan Seni Budaya di Sekolah (Vol. 31, Issue 2). https://doi.org/10.31091/ mudra.v31i2.29

Mustikasari, R. (2011). Jaring Pengaman Pencegahan Konflik: Kasus masyarakat OKU TIMUR. Universitas Islam Negeri Syarif Hodayatullah Jakarta.

Nurlia, Rosihan, A., \& Virgiana, B. (2020). Makna Pesan pada Gerakan Tarian Sada dan Sabai dalam Tradisi Budaya Komering di kabupaten Ogan Komering Ulu Timur. Jurnal Komunikasi Dan Budaya, 1(1), 36-45.

Parmadie, B., Kumbara, A. . N. A., Wirawan, A. . B., \& Sugiartha, I. G. A. (2018). Pengaruh Globalisasi Dan Hegemoni Pada Transformasi Musik Dol Di Kota Bengkulu. Mudra Jurnal Seni Budaya, 33(1), 67. https:// doi.org/10.31091/mudra.v33i1.240

Pratiwi, dkk. (2017). Balinese Arts And Culture As Tourism Commodity In Bali Tourism Promotion Videos. Mudra Jurnal Seni Budaya.

Rahmawaty, U., \& Maharani, Y. (2013). Pelestarian Budaya Indonesia Melalui Pembangunan. Jurnal Tingkat Sarjana Bidang Senirupa Dan Desain, 2(1), 1-8.

Rai Remawa, A. (2016). Inkonsistensi Ashta Kosali Pada Bangunan Hunian Bali Madya Masa Kini Di Kabupaten Gianyar. In Mudra Jurnal Seni Budaya (Vol. 31, Issue 2). https://doi.org/10.31091/mudra.v31i2.39
Renawati, P. W. (2019). Implementasi Upacara Manusa Yadnya Dalam Naskah Dharma Kahuripan ( Perspektif Teologi Hindu ). 34(September), 372-384.

Rusdiana. A. (2019). Kompilasi Materi Wasdalbindaya Bidang Jurnal 2016-2019.

Suardi, W. (2018). Catatan kecil mengenai desain riset deskriptif kualitatif. Islam Nusantara, 1(1), 1-11.

Suryada, I. G. A. B. (2014). Ornamen-ornamen Bermotif Kedok Wajah dalam Seni Arsitektur Tradisional Bali. Jurnal Sulapa, 1-11.

Syuhada, N. I. S. (2020). Seloko Adat Melayu to Building Character and Multicultural of Jambi Society. 9(2), 193213.

Wahid, A. N., Sumarlam, ., \& Subiyantoro, S. (2018). Tradisi Ziarah Makam Bathara Katong (Tinjauan Deskripsi Akulturasi Budaya). Mudra Jurnal Seni Budaya, 33(2), 215. https://doi.org/10.31091/mudra.v33i2.289

Widianti, E. (2020). Harmonisasi beragama masyarakat di desa tegal besar kecamatan belitang ii kabupaten oku timur sumatera selatan tahun 1980-2019. Universitas Muhamadiyah Palembang.

WIDIANTI, E. (2020). Harmonisasi beragama masyarakat di desa tegal besar kecamatan belitang ii kabupaten oku timur sumatera selatan tahun 1980-2019. Universitas Muhammadiya Palembang.

Widyaevan, D. A. (2019). Surrealisme dalam Arsitektur: Penerapan Inkuiri Metafisik pada Karya Arsitektur Kontemporer Yoka Sara. Mudra Jurnal Seni Budaya, 34(2), 157-164. https://doi.org/10.31091/mudra.v34i2.624

Wijaya, I. P. S. (2018). Perkembangan ornamen bali pada bangunan modern minimalis di bali. Senada (Seminar Nasional Desain Dan Arsitektur), 1, 218-223.

\section{Daftar Nara Sumber/Informan}

Muslim (55th.), Kepala Sekolah SMPN 1 Belitang III, wawancara tanggal 16 November 2020 di SMPN 1 Belitang III, Nusa Bakti, Belitang III, Ogan Komering Ulu Timur, Sumatera Selatan.

Irawanti (24 th.), Guru SMPN 1 Belitang III, wawancara tanggal 7 November 2020 di SMPN 1 Belitang III, Nusa Bakti, Belitang III, Ogan Komering Ulu Timur, Sumatera Selatan. 